\title{
Viral haemorrhagic septicaemia virus (VHSV) genotype II isolated from European river lamprey Lampetra fluviatilis in Finland during surveillance from 1999 to 2008
}

\author{
Tuija Gadd ${ }^{1, *}$, Miia Jakava-Viljanen${ }^{1}$, Katja Einer-Jensen $^{2}$, Ellen Ariel $^{2,5}$, \\ Perttu Koski ${ }^{3}$, Liisa Sihvonen ${ }^{1,4}$ \\ ${ }^{1}$ Finnish Food Safety Authority Evira, Mustialankatu 3, 00790 Helsinki, Finland \\ ${ }^{2}$ National Veterinary Institute, Technical University of Denmark, Hangøvej 2, 8200 Århus N, Denmark \\ ${ }^{3}$ Finnish Food Safety Authority Evira, PO Box 517, 90101 Oulu, Finland \\ ${ }^{4}$ Department of Basic Veterinary Sciences, Faculty of Veterinary Medicine, PO Box 66, 00014 University of Helsinki, Finland \\ ${ }^{5}$ Present address: School of Veterinary and Biomedical Sciences, James Cook University, Douglas Campus, Townsville 4811, \\ Queensland, Australia
}

\begin{abstract}
We examined the occurrence of viral haemorrhagic septicaemia virus (VHSV) in the main spawning stocks of wild European river lamprey Lampetra fluviatilis in the rivers of Finland from 1999 to 2008. Pooled samples of internal organs (kidney, liver and heart or brain) from 2621 lampreys were examined for the presence of VHSV by standard virological techniques. VHSV was isolated from 5 samples from the rivers Lestijoki and Kalajoki, which flow from Finland into the Bothnian Bay of the Baltic Sea. The presence of VHSV was confirmed by immunofluorescent antibody technique (IFAT), ELISA and RT-PCR. Phylogenetic analysis based on the full-length VHSV glycoprotein (G) gene sequence revealed that the isolates were most closely related to the VHSV strain isolated in 1996 from herring Clupea harengus and sprat Sprattus sprattus in the Eastern Gotland Basin of the Baltic Sea, and were therefore assigned to VHSV genotype II. The partial G gene sequences obtained (nt 1 to 672-1129) of all 5 lamprey VHSV isolates were identical, and so were the entire G genes (nt 1 to 1524) of 2 isolates sequenced. The virulence of one of the lamprey isolates was evaluated by an experimental infection trial in rainbow trout Oncorhynchus mykiss fry. No mortality was induced postinfection by waterborne and intraperitoneal challenge, respectively, while 2 genotype Id isolates originating from Finnish rainbow trout caused marked mortality under the same conditions. The infection in the European river lamprey is thought to be independent from the epidemic in farmed rainbow trout in Finnish brackish waters, because the isolates from rainbow trout were of a different genotype. This is the first report of VHSV found in the European river lamprey. The role of wild river lampreys in maintaining the infection in the marine environment remains unclear.
\end{abstract}

KEY WORDS: Vector of VHSV $\cdot$ Lamprey $\cdot$ Apathogenic $\cdot$ Risk $\cdot$ Epidemiology $\cdot$ Brackish water

\section{INTRODUCTION}

Viral haemorrhagic septicaemia (VHS) is a severe viral fish disease that causes significant losses in farmed rainbow trout Oncorhynchus mykiss across Europe. VHS virus (VHSV) has been isolated from a large number of free-living marine fish species in Europe, Japan and North America (Smail 1995, 2000, Dixon et al. 1997, Mortensen et al. 1999, Takano et al. 2000, King et al. 2001, Brudeseth \& Evensen 2002, Hedrick et al. 2003, Skall et al. 2005a). VHSV isolates originating from wild marine fish generally exhibit no 
or very low pathogenicity to rainbow trout (Dixon et al. 1997, Skall et al. 2004).

VHSV is an enveloped negative-strand RNA virus belonging to the Novirhabdovirus genus of the family Rhabdoviridae. The VHSV genome is a nonsegmented, single-stranded RNA molecule with a length of approximately 11200 nucleotides. The genome consists of 6 genes in the order 3'-N-P-M-G-NV-L-5', encoding 5 structural proteins: nucleocapsid (N) protein, phosphoprotein $(\mathrm{P})$, matrix protein $(\mathrm{M})$, glycoprotein $(\mathrm{G})$ and RNA polymerase protein $(\mathrm{L})$, and one nonstructural protein (NV) (Schütze et al. 1999).

VHSV isolates cluster into 4 genotypes (I to IV) with several sublineages within genotypes I (minimum Ia to Ie) and IV (IVa to IVb), which seems to correlate with the geographical regions of isolations rather than with pathogenicity (Snow et al. 1999, Einer-Jensen et al. 2004, Lumsden et al. 2007). Genotypes Ia, Ic and Id include a wide range of virus strains originating from brackish water and freshwater rainbow trout farms in Europe (Benmansour et al. 1997, Stone et al. 1997, Snow et al. 1999, Thiery et al. 2002, Einer-Jensen et al. 2004, Raja-Halli et al. 2006). In addition, 28 isolates from marine fish species found in the Baltic Sea, Skagerrak and Kattegat, and one isolate from the English Channel appear to have the same ancestral source as these strains from rainbow trout and belong to genotype Ib (Einer-Jensen et al. 2004). Genotype Ie includes isolates from the Black Sea (Einer-Jensen et al. 2004, Nishizawa et al. 2006). Genotype II so far only includes some marine isolates found in the eastern Gotland Basin of the Baltic Sea (Snow et al. 1999, Einer-Jensen et al. 2004). The third genotype (III) consists of isolates originating from outbreaks of VHS in turbot Scophthalmus maximus farms in the British Isles (Ross et al. 1994, Einer-Jensen et al. 2004), as well as isolates from a variety of marine species caught in Scottish waters and the Skagerrak (Snow et al. 1999, Einer-Jensen et al. 2004), one isolate from an eel Anguilla anguilla captured in the River Loire estuary in France (Thiery et al. 2002, Einer-Jensen et al. 2004), isolates from Greenland halibut Reinhardtius hippoglossoides caught at the Flemish Cap in the North Atlantic (LópezVázquez et al. 2006) and in 2007 to 2008 from seawater-reared rainbow trout in Storfjorden in western Norway (Dale et al. 2009). Genotype IVa includes isolates from wild marine fish in the North Pacific Ocean including the coast of the North America (Benmansour et al. 1997, Stone et al. 1997, Snow et al. 1999, Nishizawa et al. 2002), as well as isolates from Japanese flounder Paralichthys olivaceus (Nishizawa et al. 2002) and Pacific sand eel Ammodytes personatus around Japan (Watanabe et al. 2002). Isolates from the Great Lakes region of North America (Elsayed et al. 2006, Lumsden et al. 2007) and from 4 species of wild fish from the eastern Atlantic coast of Canada (Gagné et al. 2007) belong to genotype IVb.

In Finland, VHSV was diagnosed for the first time in spring 2000 from 4 rainbow trout farms in brackish water (Raja-Halli et al. 2006) around Pyhtää (P) and the Åland Islands (A) (Fig. 1). There were 4 positive farms

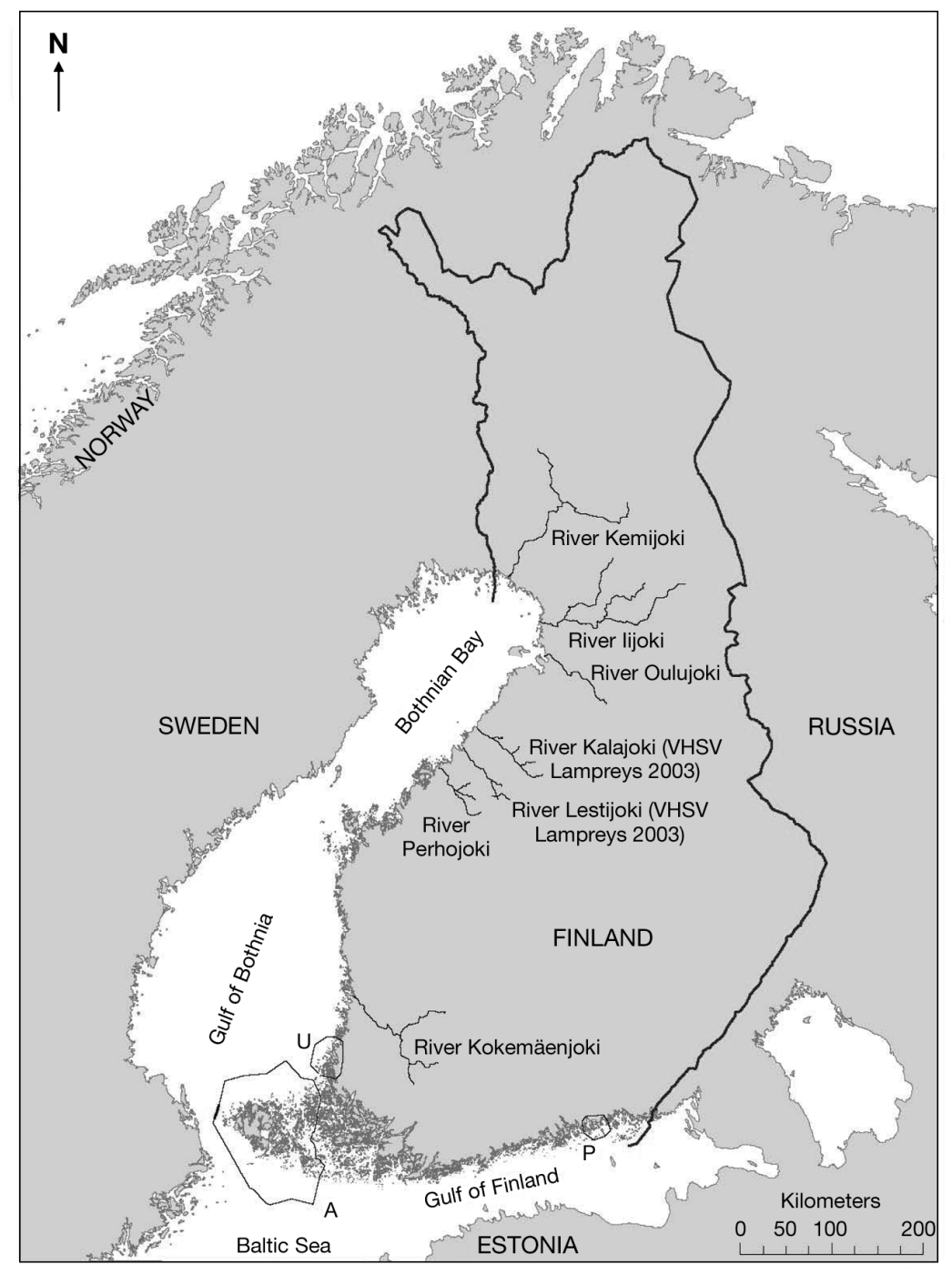

Fig. 1. Wild European river lampreys captured from the estuary of the rivers Iijoki, Oulujoki, Kalajoki (VHSV genotype II was isolated from 1 sample in 2003), Lestijoki (VHSV genotype II was isolated from 4 samples in 2003), Perhojoki and Kokemäenjoki. Restriction areas of VHSV are A: Åland Islands 2000 (whole area since 2001); P: Pyhtää 2000 to 2007; U: UusikaupunkiPyhäranta-Rauma 2003. All virus isolates are genotype Id 
in Åland waters and 2 close to Pyhtää in 2001. In 2003, VHSV was diagnosed for the first time in Uusikaupunki (U) and later again in 2008. These isolates from rainbow trout were shown to be members of genotype Id (Raja-Halli et al. 2006), and since 2000, VHSV isolates of genotype Id have been recovered in fish from 2 to 14 farms in the waters around in the Åland Islands every year. Continental Finland is considered free of VHS apart from coastal restriction areas $\mathrm{A}, \mathrm{P}$ and $\mathrm{U}$ as shown in Fig. 1. The transportation and movement of farmed fish and equipment is not allowed from the restriction area. Neither is it permitted to sell fish from facilities subject to restrictions to free areas.

The management of lamprey stocks in rivers closed by hydroelectric power stations is carried out by capturing lampreys from the estuary and transferring them above the dam wall. This requires permission from the Ministry of Agriculture and Forestry (Decision 1087/1998, MAFF 1998) and a survey of at least 60 lampreys per river each year for viral and bacterial diseases such as VHSV, infectious haemotopoietic necrosis virus (IHNV) and bacterial kidney disease (BKD, data not shown) before transferring them upstream from the migration barrier.

The aim of this study was to clarify the role of the European river lamprey Lampetra fluviatilis in the epidemiology of VHSV in Finland.

\section{MATERIALS AND METHODS}

Virus isolation and identification. Healthy adult river lampreys were caught during the spawning migration from the mouth of the spawning in rivers on the Finnish coast of the Bothnian Bay. In total, 2621 samples were collected during 1999 to 2008. Details of the sample distribution are summarised in Table 1.

Pooled heart or brain, anterior kidney and liver tissue from a maximum of 10 lampreys (= 1 sample) were processed according to standard virological procedures as described by Raja-Halli et al. (2006) and inoculated onto subconfluent monolayer cell cultures of bluegill Lepomis macrochirus fry (BF-2) and epithelioma papulosum cyprini (EPC) cell lines (Wolf et al. 1966, Fijan et al. 1983). The samples were incubated in a $\mathrm{CO}_{2}$ incubator at $16^{\circ} \mathrm{C}$ according to methods described by Raja-Halli et al. (2006) and inspected regularly with a microscope for the occurrence of cytopathic effects (CPE) at 40× magnification. After $7 \mathrm{~d}$ incubation at $16^{\circ} \mathrm{C}$, supernatant from samples without CPE was diluted to 1:100 and 1:1000, subcultured onto fresh cells and incubated for a further $7 \mathrm{~d}$. In cases where total CPE was evident, the cell culture medium was collected and stored at $-20^{\circ} \mathrm{C}$ for future studies.

Staining of cells for immunofluorescence. The indirect fluorescent antibody technique (IFAT) was used for VHSV and IHNV identification with minor modification of the method described by Raja-Halli et al. (2006). Cover glass (diameter $13 \mathrm{~mm}$, Menzel-Glaser) cultures of BF-2 cells grown in 24-well plates were inoculated at dilutions of $10^{-1}$ and $10^{-2}$. Uninfected cells served as negative controls. The infected cultures were fixed with acetone on Days 1 and 2 postinfection and the IFAT was performed as described by Lorenzen et al. (1988). Briefly, the monoclonal antibody (MAb) 1P5B11 (DTU) against the nucleocapsid $(\mathrm{N})$ protein of the VHSV-F1 strain or the MAb Hyb 136-3 (DTU) against the $\mathrm{N}$ protein of IHNV were diluted in phos-

Table 1. The number of European river lampreys and number of pooled samples investigated by standard virological procedures from Finnish rivers draining into the Gulf of Bothnia. Data are presented as no./pool where no. = number of lampreys examined and pool $=$ number of pooled samples examined. Wild lampreys are caught in the estuaries of rivers dammed for hydroelectric power and transferred upstream from the artificial migration barriers. Subsets of 60 lampreys per river were virologically examined in pooled samples of up to 10 fish per pool and also analysed for the presence of bacterial kidney disease (BKD) (results not shown). nd: none detected

\begin{tabular}{|c|c|c|c|c|c|c|c|c|c|}
\hline Year & Kemijoki & Iijoki & Oulujoki & Kalajoki & Lestijoki & Perhonjoki & Kokemäenjoki & $\begin{array}{c}\text { All } \\
\text { rivers }\end{array}$ & $\begin{array}{l}\text { All rivers } \\
\text { VHSV }\end{array}$ \\
\hline 1999 & nd & nd & nd & nd & nd & nd & $60 / 6$ & $60 / 6$ & \\
\hline 2000 & nd & nd & nd & nd & nd & nd & nd & nd & \\
\hline 2001 & nd & nd & $60 / 6$ & nd & nd & nd & nd & $60 / 6$ & \\
\hline 2002 & nd & nd & $60 / 6$ & nd & nd & $60 / 6$ & nd & $120 / 12$ & \\
\hline 2003 & $75 / 8$ & $60 / 6$ & $60 / 6$ & $60 / 6$ & $120 / 12$ & $130 / 13$ & nd & $505 / 51$ & $50 / 5^{\mathrm{a}}$ \\
\hline 2004 & nd & $60 / 6$ & $60 / 6$ & $60 / 6$ & $160 / 16$ & $160 / 15$ & $90 / 9$ & $590 / 58$ & \\
\hline 2005 & nd & $60 / 6$ & $60 / 6$ & $60 / 6$ & $60 / 6$ & $60 / 6$ & $60 / 6$ & $360 / 36$ & \\
\hline 2006 & nd & $60 / 6$ & $60 / 6$ & nd & $60 / 6$ & $80 / 8$ & & $260 / 26$ & \\
\hline 2007 & $60 / 6$ & nd & $60 / 6$ & $60 / 6$ & $60 / 6$ & $60 / 6$ & $60 / 6$ & $360 / 36$ & \\
\hline 2008 & $60 / 6$ & $60 / 6$ & $60 / 6$ & nd & nd & $66 / 7$ & $60 / 6$ & $306 / 31$ & \\
\hline Total & $195 / 20$ & $300 / 30$ & $480 / 48$ & $240 / 24$ & $460 / 46$ & $616 / 61$ & $330 / 33$ & $2621 / 262$ & $50 / 5$ \\
\hline
\end{tabular}


phate-buffered saline and applied as the first antibody on the monolayer. After 30 min incubation at $37^{\circ} \mathrm{C}$, diluted fluorescein isothiocyanate (FITC)-labelled rabbit anti-mouse immunoglobulin was added as the second antibody (DAKO A/S), and incubated for $30 \mathrm{~min}$ at $37^{\circ} \mathrm{C}$. The monolayer was washed and examined under an epifluorescence microscope. VHSV or IHNV were used as a positive controls and uninfected cells as negative controls.

ELISA. Aliquots of $50 \mu \mathrm{l}$ of culture medium from cell cultures showing evidence of $\mathrm{CPE}$ were analysed with a commercial ELISA kit according to the manufacturer's instructions (Test-Line) to test for the presence of VHSV.

RNA extraction, RT-PCR and sequencing. For nucleotide sequence analysis, total RNA was extracted from $140 \mu \mathrm{l}$ of viral supernatant from VHSV-infected cells using QIAamp® Viral RNA Mini Kit (QIAGEN), according to the manufacturer's instructions. Purified RNA samples were stored at $-70^{\circ} \mathrm{C}$ until use. The G gene sequences of the 5 isolates were RT-PCR amplified and sequenced using various primer sets (Table 2) as described by Raja-Halli et al. (2006). The generated PCR products were purified using Microspin S-400 HR Columns (Amersham Biosciences) according to the manufacturer's instructions. Sequencing was performed with an ABI PRISM 3100 Avant Genetic Analyzer (Applied Biosystems) using the PRISM Big Dye v. 3.1 Cycle Sequencing kit (Applied Biosystems). Sequences were analysed using Sequencing Analysis Software v. 5.1 (Applied Biosystems).

Analysis of sequence data. The consensus sequences of each isolate were initially compared using ClustalW2 (Larkin et al., 2007), and later edited manually. Subsequently, a nucleotide similarity search was performed with the basic local alignment search tool (BLAST, available at www.ncbi.nlm.nih.gov) and a number of representative VHSV isolates from each genotype were selected to further analyse the genetic

Table 2. Primers used for RT-PCR amplification and sequence analysis. The relative $n t$ position is given with respect to the open reading frame of each gene. Primer sets G1+ and NAH- were used for the initial RT-PCR amplification, and the sequencing included additional primers as described by Raja-Halli et al. (2006). Forward primers are marked + and reverse primers -

\begin{tabular}{|lll|}
\hline Primer & Relative position $(\mathrm{nt})$ & Sequence $\left(5^{\prime}-3^{\prime}\right)$ \\
\hline G1+ & $501-518$ in $\mathrm{M}$ gene & CGGGCAGGCGAAGGACTA \\
G2+ & $1-21$ in $\mathrm{G}$ gene & ATGGAATGGAATACTTTTTC \\
G3+ & $578-600$ in G gene & CAACCTCGCCCTGTCAAACTCAT \\
GLF+ & $1023-1042$ in G gene & TGGACCCGGCAAGGCACACT \\
G1- & $260-282$ in G gene & CGGAGACGCTGGTGACTGATA \\
G2- & $678-697$ in G gene & TGTGATCATGGGTCCTGGTG \\
G3- & $1180-1203$ in G gene & GTCCCCAAATATCATCCCATCGTA \\
NAH- & $216-235$ in NV gene & CTAGGAGACTTATCCTCATGTC \\
\hline
\end{tabular}

relationships (summarised in Table 3). The multiple sequence alignments were performed with the MegAlign program using the Clustal Method (DNASTAR) and ClustalW2 software (Larkin et al. 2007). Phylogenetic and molecular evolutionary analyses were conducted using MEGA v. 4 (Tamura et al. 2007). A phylogenetic tree was constructed from the entire G gene alignment with the maximum parsimony DNA distance method determined by 1000 data set bootstrap resampling within the MEGA program. The pairwise sequence divergences were calculated using the MegAlign program of LASERGENE, with default settings. The GeneBank/EMBL accession numbers of the sequences obtained in this study are GQ504013 and GQ504014.

Challenge experiments. VHSV isolates used in the challenge experiments were of a low (usually 3 to 7 ) passage number, and were inoculated at low multiplicity on monolayers of BF-2 cells (Lorenzen et al. 1988). At full CPE the supernatants were harvested, titrated and stored at $-20^{\circ} \mathrm{C}$ until used in trials. Isolates used in the challenge experiment are listed in Table 4.

Disinfected eggs from an IPN- and VHS-free Danish rainbow trout hatchery were brought to the quarantine area of the challenge facilities. After hatching, the fry were maintained in partly deionised, chlorine-free, running tap water at 9 to $12^{\circ} \mathrm{C}$. The challenge experiments were performed on individual fry, mean size $7.1 \mathrm{~g}$, in the biosecure challenge facility. Each challenge group consisted of 40 fish divided between two 81 aquaria, except for the bath challenge group for DK-3592B, which consisted of 60 fish divided among 3 aquaria.

Bath challenge: The water flow was turned off for $2 \mathrm{~h}$, and $4 \mathrm{ml}\left(2 \times 10^{6} \mathrm{TCID}_{50} \mathrm{ml}^{-1}\right)$ of the challenge or cell culture medium (negative control) was added to each aquarium (see Table 5).

Injection challenge: Fish were anaesthetized by immersion in $0.01 \%$ benzocaine and injected intraperitoneally (i.p.) with $50 \mu \mathrm{l}$ virus isolates mixed with $0.9 \% \mathrm{NaCl}$ to a final concentration of 1.6 to $2 \times 10^{4} \mathrm{TCID}_{50} \mathrm{ml}^{-1}$ or cell culture medium (negative control) (Table 5).

During the follow-up period of $28 \mathrm{~d}$, dead fish were collected daily and examined for clinical signs of VHS. Virological examination was performed on 5 dead fish from each aquarium; $_{i}$ fish were either dead postchallenge or killed by a benzocaine overdose at the end of the trial. Virological examination was performed according to $\mathrm{EU}$ Commission Decision 2001/183/EC. 
Table 3. Representative VHSV isolates used for phylogenetic analysis, including the accession number representing the sequenced isolates

\begin{tabular}{|c|c|c|c|c|c|}
\hline Isolate code & Year of isolation & Origin & Host species & Genotype & Accession no. \\
\hline DK-F1 & 1962 & Denmark & Rainbow trout & I & AF345857 \\
\hline DK-Hededam & 1972 & Denmark & Rainbow trout & I & Z93412 \\
\hline DK-M.Rhabdo & 1979 & Denmark & Cod & I (b) & Z93414 \\
\hline DK-1p40 & 1996 & Baltic Sea & Rockling & I (b) & AY546575 \\
\hline DK-1p52 & 1996 & Baltic Sea & Sprat & II & AY546576 \\
\hline DK-1p53 & 1996 & Baltic Sea & Herring & II & AY546577 \\
\hline DK-1p55 & 1996 & Baltic Sea & Sprat & II & AY546578 \\
\hline DK-4p168 & 1997 & Skagerrak & Herring & III & AY546582 \\
\hline DK-5131 & 1988 & Denmark & Rainbow trout & $\mathrm{I}(\mathrm{c})$ & AF345859 \\
\hline DK-5151 & 1988 & Denmark & Rainbow trout & I (a) & AF345858 \\
\hline DK-200070-4 & 2000 & Denmark & Rainbow trout & I (a) & AY546612 \\
\hline FI-ka- $66^{a}$ & 2000 & Åland, Finland & Rainbow trout & $\mathrm{I}(\mathrm{d})$ & AY546614 \\
\hline FI-FiP01.00 & 2000 & Pyhtää, Finland & Rainbow trout & $\mathrm{I}(\mathrm{d})$ & AM086355 \\
\hline FI-FiU01.03 & 2003 & Uusikaupunki, Finland & Rainbow trout & $\mathrm{I}(\mathrm{d})$ & AM086381 \\
\hline FI-lamprey-743.03 & 2003 & Finland, Lestijoki & Lamprey & II & GQ504013 \\
\hline FR-02-84 & 1984 & France & Rainbow trout & I (a) & U28800 \\
\hline FR-07-71 & 1971 & France & Rainbow trout & I (a) & AY546616 \\
\hline FR-L59X & 1987 & France & Eel & III & AY546618 \\
\hline GE-1.2 & 1981 & Georgia & Rainbow trout & I (e) & AY546619 \\
\hline IR-F13.02.97 & 1997 & Ireland & Turbot & III & AY546620 \\
\hline JP-KRRV9822 & 2000 & Japan & Japanese flounder & IV & AB179621 \\
\hline NO-A163-68 EG46 & 1968 & Norway $^{b}$ & Rainbow trout & $\mathrm{I}(\mathrm{d})$ & AY546621 \\
\hline SE-SVA-1033 & 2000 & Kattegat & Rainbow trout & I (b) & AY546623 \\
\hline UK-860/94 & 1994 & Gigha, W Scotland & Turbot & III & AY546628 \\
\hline UK-96-43 & 1996 & English Channel & Herring & I (b) & AF143862 \\
\hline UK-MLA98/6 PT11 & 1998 & North Sea & Norway pout & III & AY546632 \\
\hline US-Makah & 1988 & Washington, USA & Coho salmon & IV & U28747 \\
\hline
\end{tabular}

Table 4. List of VHSV isolates used in the challenge experiment for intraperitoneal (i.p.) injection or bath challenge

\begin{tabular}{|c|c|c|c|c|c|}
\hline Isolate name & Year isolated & Region & Genotype & Host species & Accession no. \\
\hline DK-3592 & 1986 & Denmark & $\mathrm{Ia}^{\mathrm{a}}$ & Rainbow trout ${ }^{b}$ & X66134 \\
\hline DK-1p53 & 1996 & Baltic Sea & $\mathrm{II}^{\mathrm{a}}$ & Herring & AY546577 \\
\hline FI-ka-66 & 2000 & Finland, Åland Islands & $\mathrm{Id}^{\mathrm{a}}$ & Rainbow trout ${ }^{\mathrm{d}}$ & AY546614 \\
\hline FI-lamprey-743.03 & 2003 & Finland, River Kalajoki & II & Lamprey & GQ504013 \\
\hline \multicolumn{6}{|c|}{${ }^{\mathrm{a}}$ The indicated genotypes are according to Einer-Jensen et al. (2004) } \\
\hline \multicolumn{6}{|c|}{ 'bsolated from a VHSV outbreak in freshwater } \\
\hline \multicolumn{6}{|c|}{${ }^{c}$ FI-ka-66 is the same strain as FiA01.00 (Raja-Halli et al. 2006) } \\
\hline \multicolumn{6}{|c|}{${ }^{\mathrm{d}}$ Rainbow trout were certified VHS free before transfer from freshwater } \\
\hline
\end{tabular}

\section{RESULTS}

\section{Virus isolation and identification}

VHSV was isolated from 5 pooled samples originating from the River Lestijoki (4 samples) and the River Kalajoki (1 sample). CPE were only detected in the BF2 cell line. The 5 isolated viruses were identified as VHSV by ELISA, IFAT and RT-PCR (Table 6).

\section{Genetic analysis}

Sequences of the entire G gene (1524 nucleotides) were determined for a VHS strain isolated from wild river lampreys from the River Kalajoki (Fi-lamprey739.03) and for 1 strain isolated from the River Lestijoki (FI-lamprey-743.03). For the 3 other lamprey isolates from the River Lestijoki, only the partial G gene sequences were determined from Fi-lamprey-737.03, 
Table 5. Summary of the rainbow trout challenge experiment. Virus titres were adjusted to $1.6-5 \times 10^{4}$ or $2 \times 10^{6}$ and used in intraperitoneal (i.p.) injection or bath challenge, respectively. The average cumulative mortality per challenge group as well as the recorded mortality within individual tanks is listed along with the results obtained from virological examination

\begin{tabular}{|c|c|c|c|c|}
\hline Isolate name & $\begin{array}{l}\text { Challenge } \\
\text { method }\end{array}$ & $\begin{array}{c}\mathrm{TCID}_{50} \\
\mathrm{ml}^{-1}\end{array}$ & $\begin{array}{c}\text { Average \% } \\
\text { mortality } \\
\text { (\% mortality within } \\
\text { individual tanks) }\end{array}$ & $\begin{array}{l}\text { Proportion of } \\
\text { VHSV-positive } \\
\text { fish in virological } \\
\text { examination }\end{array}$ \\
\hline \multirow[t]{2}{*}{ DK-3592 } & Injection & $1.6 \times 10^{4}$ & $\begin{array}{c}100 \\
(19 / 19,20 / 20)\end{array}$ & $10 / 10$ \\
\hline & Bath & $2 \times 10^{6}$ & $\begin{array}{c}98 \\
(20 / 20,19 / 20,20 / 20)\end{array}$ & $15 / 15$ \\
\hline \multirow[t]{2}{*}{ DK-1p53 } & Injection & $5 \times 10^{4}$ & $\begin{array}{c}0 \\
(0 / 20,0 / 20)\end{array}$ & $0 / 10$ \\
\hline & Bath & $2 \times 10^{6}$ & $\begin{array}{c}0 \\
(0 / 20,0 / 21)\end{array}$ & $0 / 10$ \\
\hline \multirow[t]{2}{*}{ FI-ka-66 } & Injection & $2.5 \times 10^{4}$ & $\begin{array}{c}66 \\
(12 / 19,13 / 19)\end{array}$ & $8 / 10$ \\
\hline & Bath & $2 \times 10^{6}$ & $\begin{array}{c}13 \\
(5 / 20,0 / 20)\end{array}$ & $5 / 10$ \\
\hline \multirow[t]{2}{*}{$\begin{array}{l}\text { FI-lamprey- } \\
743.03\end{array}$} & Injection & $5 \times 10^{4}$ & $\begin{array}{c}0 \\
(0 / 20,0 / 20)\end{array}$ & $0 / 10$ \\
\hline & Bath & $2 \times 10^{6}$ & $\begin{array}{c}0 \\
(0 / 20,0 / 20)\end{array}$ & $0 / 10$ \\
\hline \multirow[t]{2}{*}{ Medium only } & Injection & & $\begin{array}{c}0 \\
(0 / 19,0 / 20)\end{array}$ & $0 / 10$ \\
\hline & Bath & & $\begin{array}{c}0 \\
(0 / 20,0 / 20)\end{array}$ & $0 / 10$ \\
\hline
\end{tabular}

Table 6. VHSV genotype II isolates from European river lampreys in Finland

\begin{tabular}{|c|c|c|c|c|c|}
\hline Isolate code & $\begin{array}{c}\text { Virus i } \\
\text { BF-2 }\end{array}$ & $\begin{array}{c}\text { olation } \\
\text { EPC }\end{array}$ & ELISA & IFAT & $\begin{array}{c}\text { Length of } \\
\text { obtained } \\
\text { sequences (bp) }\end{array}$ \\
\hline FI-lamprey-737.03 & pos & neg & pos & pos & 1129 \\
\hline FI-lamprey-738.03 & pos & neg & pos & pos & 672 \\
\hline FI-lamprey-739.03 & pos & neg & pos & pos & 1524 \\
\hline FI-lamprey-740.03 & pos & neg & pos & pos & 673 \\
\hline FI-lamprey-743.03 & pos & neg & pos & pos & 1524 \\
\hline
\end{tabular}

1129 nucleotides (nt positions 1 to 1129), Fi-lamprey738.03, 672 nucleotides (nt positions 1 to 672), and Filamprey-740.03, 673 nucleotides (nt positions 1 to 673), respectively (Table 6).

Pairwise comparisons of the sequenced regions revealed that all isolates were $100 \%$ identical (data not shown). The genetic relationships of the entire G genes between the Finnish lamprey isolate (FI-lamprey743.03) and some representative isolates from the other known genotypes (I to IV, Snow et al. 1999, 2004, EinerJensen et al. 2004) are illustrated in Fig. 2. Within the genetically and geographically heterogeneous VHSV genotypes, the Finnish lamprey isolate was grouped in genotype II, together with strains isolated in 1996 from herring Clupea harengus (DK-1p53) and sprat Sprattus sprattus (DK-1p52) in Gotland, both of which had boot- strap values that were $99 \%$ identical to lamprey. The Finnish consensus sequence was subsequently compared with the representative gene sequences summarised in Table 3. The genetic analysis revealed that the VHSV isolates from the geographically closest areas, represented by a Swedish marine isolate (SE-SVA-1033) and the Finnish rainbow trout isolates FiP01.00, FiA01.00 and FiU01.03, were of genotype Id and shared only 89 to $90 \%$ identity with the lamprey isolate.

\section{Infection trial}

No mortality was observed in the groups of rainbow trout challenged either with the marine FI-lamprey 743.03 or the DK-1p53 genotype II isolates during the $28 \mathrm{~d}$ trial period. However, 98 to $100 \%$ of fish exposed to the genotype Id isolate DK-3592B from freshwater-reared rainbow trout died within $14 \mathrm{~d}$ postchallenge. These results were identical for both routes of infection. In the case of the FI-ka-66 isolate from trout (brackish water), $66 \%$ of fish died after the i.p. injection challenge, whereas only $13 \%$ died after the bath challenge. The mortality curves are illustrated in Fig. 3. The variation between the duplicate tanks was minimal (Table 5). No mortality was observed in the mock-infected groups (cell culture medium).

\section{DISCUSSION}

This study provided unique survey data information on the VHSV status of river lampreys in Finland over a period of $10 \mathrm{yr}$. In total 2621 individuals represented by 262 pooled samples were examined. Only 5 VHSVpositive pools were detected during 2003 at a rate of 4 out of $6(4 / 6)$ pooled samples in the River Lestijoki and 1 out of $6(1 / 6)$ pooled samples in the River Kalajoki. In our laboratory, the VHSV genotype II isolates from lamprey only grew in the BF-2 cell line, whereas VHSV genotype I isolates from rainbow trout grew in both BF-2 and EPC cell lines. Further estimation of the prevalence of infection in the rivers Lestijoki and Kalajoki proved to be difficult because the sample sizes were limited. 


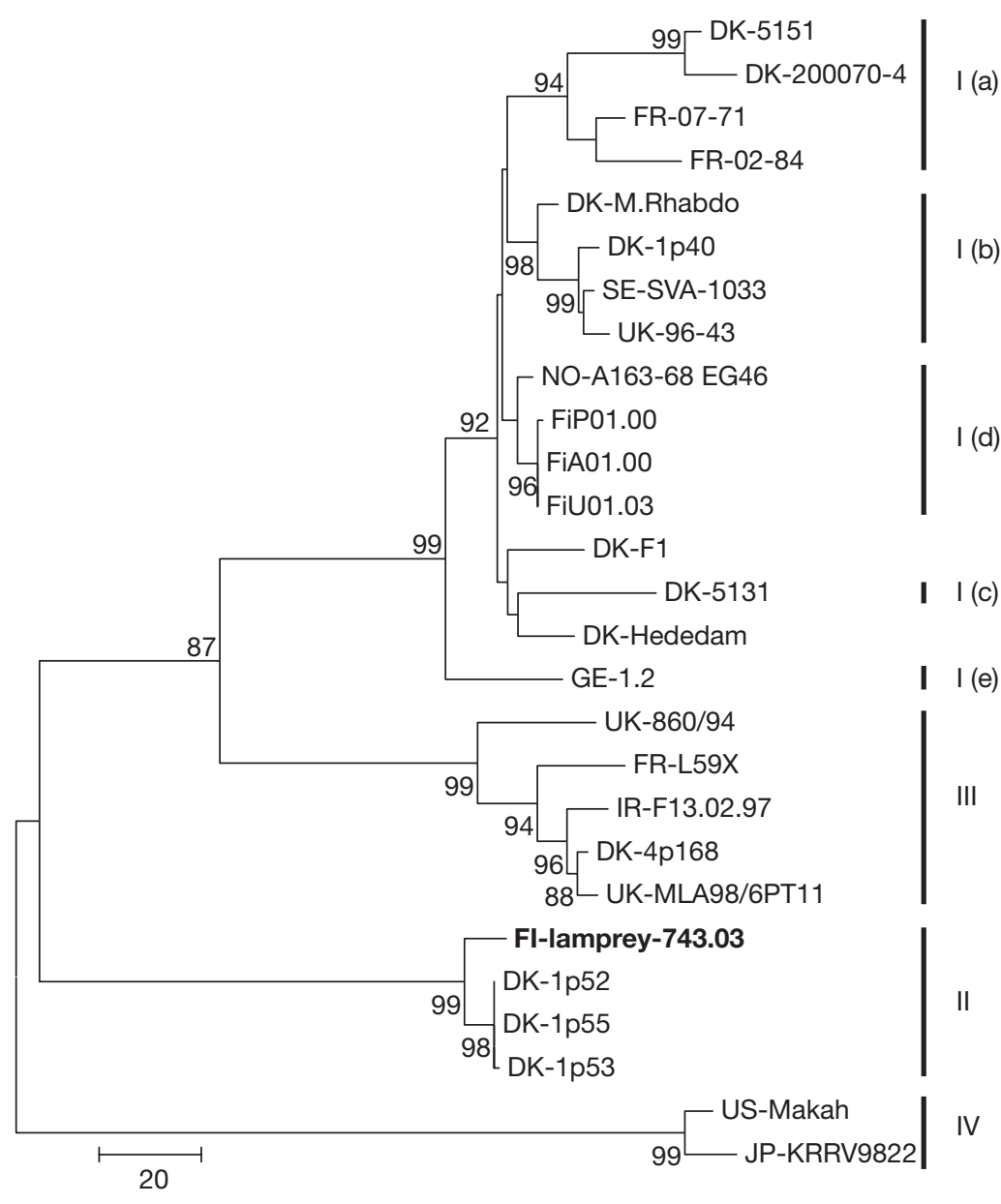

Fig. 2. Maximum parsimony phylogenetic tree obtained using the entire $G$ gene of VHSV. The scale bars indicate the phylogenetic distances. Bootstrap values are indicated at the nodes for a total of 1000 replicates. Sequence alignments were performed using ClustalW2. Phylogenetic trees were constructed using the Maximum Parsimony DNA distance method within the MEGA program. The origin of the representative VHSV isolates used for phylogenetic analysis is shown in Table 3

We demostrated that river lampreys harbour active VHSV infections, like many other wild marine fish species (Smail 1995, 2000, Dixon et al. 1997, Mortensen et al. 1999, Takano et al. 2000, King et al. 2001, Brudeseth \& Evensen 2002, Hedrick et al. 2003, Skall et al. 2005a). Horizontal transmission from infected fish to naive fish via excreta is thought to be the main mode of transmitting VHS (Nilson \& Fänge 1970), but lampreys are also potential candidates for mechanical transfer of VHSV due to their parasitic feeding habits on live fish and their ability to move from host to host. Lampreys are cyclostomes (superclass: Agnatha), which do not have a stomach and do not secrete hydrochloric acid (Hardisty 1979). The $\mathrm{pH}$ in the alimentary canal of cyclostomes is not in the range needed for the inactivation of VHSV (Neukirch 1985), which may aid in their role as potential mechanical vectors of VHSV.
The feeding migration of river lampreys in the Baltic Sea has been described by Tuunainen et al. (1980) based on the observations of fishers. Lampreys are pelagic, often attaching themselves to herring or sprat used as bait on salmon drift lines. Lamprey feeding scars have been found on herring and cod Gadus morhua along the Finnish coast, but scarring caused by lampreys has not been reported on Atlantic salmon Salmo salar, sea trout Salmo trutta trutta or whitefish Coregonus lavareti. According to fish farmers in the region where the most important lamprey spawning rivers of Finland enter the Bothnian Bay, lamprey scars or attacks on farmed rainbow trout have not been observed by local fish farmers (J. Väätäjä pers. comm.).

It is not known whether lampreys pose a serious threat of transmitting VHS to farmed fish. However, as the attachment of lampreys to farmed salmonids in net cages appears to be a rare phenomenon, it is unlikely that they act as mechanical vectors of the disease among farmed salmonids. The results of our study support this view in that VHSV isolates from European river lampreys were of genotype II, while all isolates from farmed fish - mainly rainbow trout — in the Baltic Sea have been of type Ib or Id (EinerJensen et al. 2004, Raja-Halli et al. 2006). Thus, there is no apparent connection between the VHSV epidemic in brackish water trout farms and the findings of VHSV in lampreys reported here. However, like other infected fish in the waters surrounding cages, they could be presumed to excrete the virus into the environment and thereby potentially transmit VHS to farmed fish. It is also possible that they could play a role in the transmission of VHS between individual herring and sprat, species that also appear to be their natural hosts and are known to harbour the VHS virus (Hershberger et al. 1999, Skall et al. 2005b).

In our study, about 8900 lampreys caught in the estuary of the rivers Lestijoki and Kalajoki had already been transferred to the neighbouring River Perhonjoki, where the first obstacle to their migration is situated about $25 \mathrm{~km}$ upstream. In the River Perhonjoki the power station has a compensatory obligation to transfer about 12500 brood river lampreys over the dam as well as to stock 10 million larvae to suitable areas. Lampreys do not feed during the winter, but they adhere to stones and other substrata and lay eggs or 


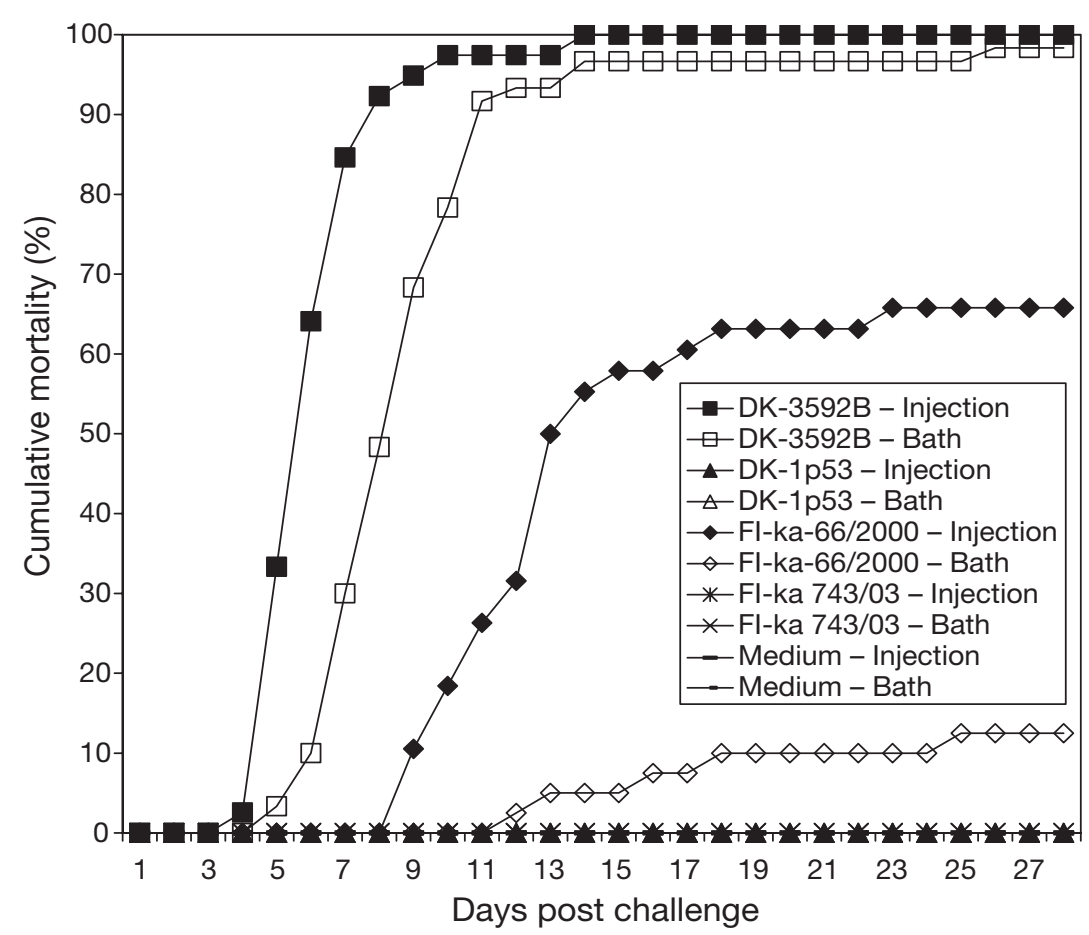

Fig. 3. Development of mortality in rainbow trout after being challenged with the various VHSV isolates. Each curve represents the cumulative percentage mortality of 2 aquaria, each with 20 fish. The only exception was the bath challenge with isolate DK-3592B, which was carried out using 3 aquaria (60 fish in total)

release sperm in the following spring, after which they all die. Hatched larvae burrow into the bottom sediment and remain there for several years until they migrate to the sea.

No fish farms are situated in the water courses of the rivers Perhonjoki or Kalajoki, but on River Lestijoki there is one farm growing both brown trout Salmo trutta fario and whitefish. This farm has been examined for the presence of VHSV since 1995 using methods specified in EU Commission Decision 2001/183/EC (Anonymous 2001), and all examined samples have been negative. The VHSV isolates from the wild lampreys captured from the estuary of the rivers Lestijoki and Kalajoki belong to genotype II. Both rivers flow into the Bothnian Bay of the Baltic Sea, more than $300 \mathrm{~km}$ from the nearest VHS-positive farm. Before isolates from European river lamprey were identified, genotype II only included isolates from fish caught in the narrow region referred to as the eastern Gotland Basin (Baltic Sea). It is possible that genotype II is more widespread than the known distribution or that European river lampreys migrate to the eastern Gotland Basin and become infected there.

Since 2000, VHSV has mainly been found in Finnish rainbow trout farms located near the Åland Islands (restriction areas in Fig. 1). The rainbow trout isolates all belong to genotype Id and are phylogenetically positioned close to the common ancestor of marine and freshwater isolates. The observed presence of 2 relatively different genotypes (identity level 87 to $90 \%$ ) within the Baltic Sea could, therefore, be a result of differences in genetic evolution within the biotopes or of 2 separate introduction events in this area (EinerJensen et al. 2004). However, within the last $10 \mathrm{yr}$, several events have illustrated that the host spectrum and virulence of VHSV can evolve rapidly. Phylogenetic analyses have indicated that the European genotype I lineages have a common ancestral source. Outbreaks of VHSV without physical linkage to freshwater VHSV have occurred in Scandinavian marine-reared rainbow trout (Einer-Jensen et al. 2004), indicating that the virulence in rainbow trout is not geno-subtype restricted. This theory was further supported by the finding that genotype Ib isolates from outbreaks of VHS in Swedish net pens in the Kattegat were almost identical to isolates found in the surrounding marine environment (99\% identity within the G genes) (Einer-Jensen et al. 2004). In addition, Dale et al. (2009) recently diagnosed pathogenic VHSV genotype III isolates in a Norwegian rainbow trout farm for the first time.

Selected genetically similar VHSV isolates $(>99.4 \%$ G-protein identity) showed different virulence for juvenile rainbow trout in both i.p. injection and immersion challenges $(75.0$ and $15.4 \%$, respectively, as opposed to $<35.0$ and $<2.0 \%$ ) (K. Einer-Jensen unpubl. data, Campbell et al. 2009). Although RNA viruses are prone to mutation, only 5 amino acid differences were identified throughout the entire genomes, indicating that only a few substitutions may influence the host specificity and/or pathogenicity of VHSV. The recent massive die-offs among wild fish populations in the Great Lakes of North America is a reminder of the capacity of VHSV to adapt to a wide range of hosts (Elsayed et al. 2006, Gagné et al. 2007, Groocock et al. 2007, Lumsden et al. 2007). The US Fish and Wildlife Service isolated the Great Lakes strain of VHSV genotype IV-b from invasive sea lampreys Petromyzon marinus collected from northern Lake Huron tributaries (Anonymous 2008), and fisheries managers located within this enormous water system are, therefore, concerned that the virulent virus will spread to aquaculture species. This is especially worrying because the 
isolates belong to the only sublineage outside of Europe that has been associated with significant mortality in freshwater species.

According to Skall et al. (2004), VHSV isolates from wild marine fish were generally nonpathogenic or of very low virulence by immersion challenge for rainbow trout, but significant mortality with clinical signs of VHS was observed when wild marine fish isolates were injected intraperitoneally. Finnish VHSV genotype Id strains induced a mortality of approximately $40 \%$ when infected by immersion (Raja-Halli et al. 2006, this study), which is lower than mortality caused by VHSV isolates from freshwater rainbow trout farms (Skall et al. 2004). There is evidence that a nonpathogenic form of VHSV may become more virulent after passage through rainbow trout (Snow \& Cunningham 2000, Skall et al. 2004).

Based on our findings, it seems that the infections of European river lamprey with VHSV are not linked to the rainbow trout infections in Finland. No mortality was observed during the infection trial in which rainbow trout were challenged with the lamprey isolate FI-lamprey 743.03. Nevertheless, due to the lack of knowledge of the molecular basis of VHSV pathogenicity, the potential threat that lamprey strains of VHSV may pose to the environment and the fish farming industry cannot be ignored.

Acknowledgements. This study was partly financially supported by the Ministry of Agriculture in Finland. Staff at the Research Department at Evira, especially C. Ek-Kommonen, E. Rimaila-Pärnänen, M. Raja-Halli, M. Eriksson-Kallio, P. Anttila, K. Inkinen and M. Tyllilä, are acknowledged for helping in the diagnosis of fish samples. Special thanks to L. Nuotio for help in preparing the map. L. Kaartinen is acknowledged for a critical review and fruitful criticism of the manuscript. Warm thanks to T. E. Kjær, N. Nicolaijsen, S. Madsen, M. Eliassen, H. Frank Skall, H. Buchholtz and L. Troels for their excellent assistance in connection with the infection trial at DTU.

\section{LITERATURE CITED}

Anonymous (2001) Commission Decision 2001/183/EC of 22 February 2001 laying down the sampling plans and diagnostic methods for the detection and confirmation of certain fish diseases and repealing Decision 92/532/EEC. Off J Euro Commun L 067:0065-0076

Anonymous (2008) Viral hemorrhagic septicemia virus (VHSv) isolated from sea lamprey. US Fish Wildl Serv. www.fws.gov/midwest/LaCrosseFishHealthCenter/ Documents/Winter 2008Newstr.pdf

Benmansour A, Basurco B, Monnier AF, Vende P, Winton JR, de Kinkelin P (1997) Sequence variation of the glycoprotein gene identifies three distinct lineages within field isolates of viral haemorrhagic septicaemia virus, a fish rhabdovirus. J Gen Virol 78:2837-2846

Brudeseth BE, Evensen Ø (2002) Occurrence of viral haemorrhagic septicaemia virus (VHSV) in wild marine fish species in the coastal regions of Norway. Dis Aquat Org 52: $21-28$
Campbell S, Collet B, Einer-Jensen K, Secombes CJ, Snow M (2009) Identifying potential virulence determinants in viral haemorrhagic septicaemia virus (VHSV) for rainbow trout. Dis Aquat Org 86:205-212

Dale OB, Ørpetveit I, Lyngstad TM, Kahns S, Skall HF, Olesen NJ, Dannevig BH (2009) Outbreak of viral haemorrhagic septicaemia (VHS) in seawater-farmed rainbow trout in Norway caused by VHS virus Genotype III. Dis Aquat Org 85:93-103

Dixon PF, Feist S, Kehoe E, Parry L, Stone DM, Way K (1997) Isolation of viral haemorrhagic septicaemia virus from Atlantic herring Clupea harengus from the English Channel. Dis Aquat Org 30:81-89

> Einer-Jensen K, Ahrens P, Forsberg R, Lorenzen N (2004) Evolution of the fish rhabdovirus viral haemorrhagic septicaemia virus. J Gen Virol 85:1167-1179

Elsayed E, Faisal M, Thomas M, Whelan G, Batts W, Winton J (2006) Isolation of viral hemorrhagic septicemia virus from muskellunge, Esox masquinongy (Mitchill), in Lake St. Clair, Michigan, USA reveals a new sub-lineage of the North American genotype. J Fish Dis 29:611-619

Fijan N, Sulimanović D, Bearzotti M, Muzinić D and others (1983) Some properties of the Epithelioma papulosum cyprini (EPC) cell line from carp (Cyprinus carpio). Ann Inst Pasteur Virol 134:207-220

Gagné N, Mackinnon AM, Boston L, Souter B, Cook-Versloot M, Griffiths S, Olivier G (2007) Isolation of viral haemorrhagic septicaemia virus from mummichog, stickleback, striped bass and brown trout in eastern Canada. J Fish Dis 30:213-223

Groocock GH, Getchell RG, Wooster GA, Britt KL and others (2007) Detection of viral hemorrhagic septicemia in round gobies in New York State (USA) waters of Lake Ontario and the St. Lawrence River. Dis Aquat Org 76:187-192

Hardisty MW (1979) Biology of the cyclostomes. Chapman \& Hall, London

Hedrick RP, Batts WN, Yun S, Traxler GS, Kaufman J, Winton JR (2003) Host and geographic range extensions of the North American strain of viral hemorrhagic septicaemia virus. Dis Aquat Org 55:211-220

> Hershberger PK, Kocan RM, Elder NE, Meyers TR, Winton JR (1999) Epizootiology of viral hemorrhagic septicemia virus in Pacific herring from the spawn-on-kelp fishery in Prince William Sound, Alaska, USA. Dis Aquat Org 37:23-31

> King JA, Snow M, Smail DA, Raynard RS (2001) Distribution of viral haemorrhagic septicaemia virus in wild fish species of the North Sea, northeast Atlantic Ocean and Irish Sea. Dis Aquat Org 47:81-86

- Larkin MA, Blackshields G, Brown NP, Chenna R and others (2007) ClustalW and ClustalX version 2. Bioinformatics 23: $2947-2948$

> López-Vázquez C, Raynard RS, Bain N, Snow M, Bandín I, Dopazo CP (2006) Genotyping of marine viral haemorrhagic septicaemia virus isolated from the Flemish Cap by nucleotide sequence analysis and restriction fragment length polymorphism patterns. Dis Aquat Org 73:23-31

$>$ Lorenzen N, Olesen NJ, Vestergard Jorgensen PE (1988) Production and characterization of monoclonal antibodies to four Egtved virus structural proteins. Dis Aquat Org $4: 35-42$

> Lumsden JS, Morrison B, Yason C, Russell S and others (2007) Mortality event in freshwater drum Aplodinotus grunniens from Lake Ontario, Canada, associated with viral haemorrhagic septicemia virus, Type IV. Dis Aquat Org 76:99-111

MAFF (Ministry of Agriculture and Forestry of Finland) (1998) Permission for the management of lamprey 
stocks in rivers closed by weir/weirs carried out by capturing lampreys from the estuary and transferring them across the migration barrier. Decision of the Ministry of Agriculture and Forestry of Finland (1087/1998). www. finlex.fi/fi/laki/alkup/2008/20080470

Mortensen HF, Heuer OE, Lorenzen N, Otte L, Olesen NJ (1999) Isolation of viral haemorrhagic septicaemia virus (VHSV) from wild marine species in the Baltic Sea, Kattegat, Skagerrak and the North Sea. Virus Res 63: 95-106

Neukirch M (1985) Uptake, multiplication and excretion of viral haemorrhagic septicaemia virus in rainbow trout (Salmo gairdneri). In: Ellis AE (ed) Fish and shellfish pathology. Academic Press, London, p 295-300

Nilson A, Fänge R (1970) Digestive proteases in the cyclostome Myxine glutinosa (L.). Comp Biochem Physiol 32: 237-250

Nishizawa $T$, Iida $H$, Takano $R$, Isshiki $T$, Nakajima $K$, Muroga K (2002) Genetic relatedness among Japanese, American and European isolates of viral hemorrhagic septicaemia virus (VHSV) based on partial G and P genes. Dis Aquat Org 48:143-148

Nishizawa $\mathrm{T}$, Savas $\mathrm{H}$, Isidan $\mathrm{H}$, Ustünda $\mathrm{C}$, Iwamoto $\mathrm{H}$, Yoshimizu M (2006) Genotyping and pathogenicity of viral hemorrhagic septicemia virus from free-living turbot (Psetta maxima) in a Turkish coastal area of the Black Sea. Appl Environ Microbiol 72:2373-2378

Raja-Halli M, Vehmas TK, Rimaila-Pärnänen E, Sainmaa S, Skall HF, Olesen NJ, Tapiovaara H (2006) Viral haemorrhagic septicaemia (VHS) outbreaks in Finnish rainbow trout farms. Dis Aquat Org 72:201-211

Ross K, McCarthy U, Huntly PJ, Wood BP and others (1994) An outbreak of viral haemorrhagic septicaemia (VHS) in turbot (Scophthalmus maximus) in Scotland. Bull Eur Assoc Fish Pathol 14:213-214

Schütze H, Mundt E, Mettenleiter TC (1999) Complete genomic sequence of viral hemorrhagic septicaemia virus, a fish rhabdovirus. Virus Genes 19:59-65

Skall HF, Slierendrecht WJ, King JA, Olesen NJ (2004) Experimental infection of rainbow trout Oncorhynchus mykiss with viral haemorrhagic septicaemia virus isolates from European marine and farmed fishes. Dis Aquat Org 58: 99-110

Skall HF, Olesen NJ, Mellergaard S (2005a) Prevalence of viral haemorrhagic septicaemia virus in Danish marine fishes and its occurrence in new host species. Dis Aquat Org 66:145-151

Skall HF, Olesen NJ, Mellergaard S (2005b) Viral haemorrhagic septicaemia virus in marine fish and its implications

Editorial responsibility: Gregory Chinchar,

Jackson, Mississippi, USA for fish farming - a review. J Fish Dis 28:509-529

Smail DA (1995) Isolation and identification of viral haemorrhagic septicaemia (VHS) virus from North Sea cod (Gadus morhua L.). ICES Maricult Comm Rep CM 1995/ F:15

Smail DA (2000) Isolation and identification of viral haemorrhagic septicaemia (VHS) viruses from cod Gadus morhua with the ulcus syndrome and from haddock Melanogrammus aeglefinus having skin haemorrhages in the North Sea. Dis Aquat Org 41:231-235

Snow M, Cunningham CO (2000) Virulence and nucleotide sequence analysis of marine viral haemorrhagic septicaemia virus following in vivo passage in rainbow trout Oncorhynchus mykiss. Dis Aquat Org 42:17-26

Snow M, Cunningham CO, Melvin WT, Kurath G (1999) Analysis of the nucleoprotein gene identifies distinct lineages of viral haemorrhagic septicaemia virus within the European marine environment. Virus Res 63:35-44

Snow M, Bain N, Black J, Taupin V and others (2004) Genetic population structure of marine viral haemorrhagic septicaemia virus (VHSV). Dis Aquat Org 61:11-21

Stone DM, Way K, Dixon PF (1997) Nucleotide sequence of the glycoprotein gene of viral haemorrhagic septicaemia (VHS) viruses from different geographical areas: a link between VHS in farmed fish species and viruses isolated from North Sea cod (Gadus morhua L.). J Gen Virol 78: $1319-1326$

Takano R, Nishizawa T, Aritmoto M, Muroga K (2000) Isolation of viral haemorrhagic septicaemia virus (VHSV) from wild Japanese flounder, Paralichthys olivaceus. Bull Eur Assoc Fish Pathol 20:186-192

Tamura K, Dudley J, Nei M, Kumar S (2007) MEGA4: molecular evolutionary genetics analysis (MEGA) software version 4.0. Mol Biol Evol 24:1596-1599

Thiéry R, de Boisséson C, Jeffroy J, Castric J, de Kinkelin P, Benmansour A (2002) Phylogenetic analysis of viral haemorrhagic septicaemia virus (VHSV) isolates from France (1971-1999). Dis Aquat Org 52:29-37

> Tuunainen P, Ikonen E, Auvinen H (1980) Lamprey and lamprey fisheries in Finland. Can J Fish Aquat Sci 37: 1953-1959

Watanabe L, Pakingking RJ, Iida H, Nishizawa T, Iida Y, Arimoto M, Muroga K (2002) Isolation of aquabirnavirus and viral hemorrhagic septicemia virus (VHSV) from wild marine fishes. Fish Pathol 37:189-191

- Wolf K, Gravell M, Malsberger RG (1966) Lymphocystis virus: isolation and propagation in centrarchid fish cell lines. Science 151:1004-1005

Submitted: August 31, 2009; Accepted: October 16, 2009 Proofs received from author(s): February 1, 2010 